Vol. 11, No. 1, 2021

\title{
OHMIC CONTACTS TO N-TYPE AND P-TYPE GALLIUM ANTIMONIDE WHISKERS
}

\author{
Anatoly Druzhinin, Igor Ostrovskii, Yuriy Khoverko, Oleksiy Kutrakov, \\ Natalia Liakh-Kaguy, Dmytro Chemerys \\ Lviv Polytechnic National University, Lviv, Ukraine \\ anatolii.o.druzhynin@lpnu.ua,ihor.p.ostrovskyi@lpnu.ua, yurii.m.khoverko@lpnu.ua, \\ oleksii.p.kutrakov@lpnu.ua,nataliia.s.liakh-kahui@lpnu.ua,dmytro.v.chemerys@lpnu.ua
}

\begin{abstract}
The ohmic contacts to the n-type conductivity gallium antimonide whiskers were created due to a current pulse shaper. It was established that I$\mathrm{V}$ characteristics of $\mathrm{GaSb}$ whiskers at low temperatures are linear, regardless of the direction of current transmission. That allows using the investigated techniques to create electrical contacts and study their electrophysical characteristics. GaSb samples with a diameter of $12 \mu \mathrm{m}$ and $20 \mu \mathrm{m}$ were studied at temperatures $4.2 \mathrm{~K}$ and $77 \mathrm{~K}$. A slide table with bath and microfurnace was made for welding ohmic contacts to $\mathrm{GaSb}$ whiskers. Gold microwire with a diameter of $30 \mu \mathrm{m}$ was used as a contact material. The melting was carried out under the flux layer. It was revealed that the fusion is one of the most suitable methods for creating contacts to the whiskers grown by gas transport reactions.
\end{abstract}

Key words: n-type and p-type conductivity gallium antimonide whiskers; ohmic contacts; $\mathrm{I}-\mathrm{V}$ characteristics.

\section{Introduction}

The task of creating a metal-semiconductor contact is of particular importance to the technology of manufacturing strain gages. Electrodes are areas of semiconductor whiskers, which have corresponding properties, such as magnitude and the type of conductivity, distribution of the dopping impurities, etc. Electrical contacts are needed to supply the required electrical potentials to the electrodes. Ideal contacts should be characterized by the following parameters: the value of the voltage on contacts must be minimal during current flowing through them; the contact must be linear, so the change in the magnitude and sign of the current through the contact should not caused a change in its resistance. The execution of these properties presupposes that contacts in semiconductor devices should be ohmic with the minimum possible values of transient resistance. In addition, the contact must be mechanically strong, reliable and stable over time. The contact resistance must also be independent of deformation.

As a rule, in practice, created contacts meet the above requirements only to a certain extent. It is only important that the deviation of their properties from the ideal does not significantly affect the operation of the devices. In low-power devices, the contacts can only be linear up to a certain current value.

However, there are a number of technological difficulties that encourage the search for new approaches to the creation of semiconductor structures $[1,2]$. The authors of $[3,4]$ performed metallization on $\mathrm{GaSb}$ samples due to such structures as $\mathrm{Pd} / \mathrm{Ge} / \mathrm{Pd} / \mathrm{In} / \mathrm{Pd} / \mathrm{Pt} / \mathrm{Au}$. Materials characterization using cross-sectional transmission electron microscopy confirms that gallium indium antimonide alloy $\left(\mathrm{Ga}_{x} \mathrm{In}_{1-\mathrm{x}} \mathrm{Sb}\right)$ forms at the metalsemiconductor interface, and its formation is believed to be responsible for ohmic behavior. In $[5,6]$ we can observe recommendations for the use of other materials that can serve as contact materials for compounds A3B5, including GaSb. In study [7], the authors state that the reaction between $\mathrm{Au}$ or Au-based metallization and $\mathrm{GaSb}$ takes place even at temperatures as low as $180^{\circ} \mathrm{C}$. Ga and $\mathrm{Sb}$ appear at the surface of the contact at temperatures above $250^{\circ} \mathrm{C}$.

Often, in order for making the electrical contact with the electrode ohmic with a low transient resistance, the properties of the semiconductor layer adjacent to the metal need to be changed in some way. The desired contact properties are best achieved in two cases. The first one takes place when the layer of semiconductor adjacent to the metal contains an extremely large number of recombination centers. The second one occurs when such a layer has a high electrical conductivity of the same type as the electrical conductivity of the section of the semiconductor with which the contact is established [8-10]. To provide the desired properties to the contact region of the semiconductor, the same methods can be used as those for obtaining transitions: melt growth, fusion, diffusion and epitaxial growth. Sometimes structural imperfections are created in the contact layer by means of machining in order to increase the number of recombination centers.

In principle, to create a direct metal-semiconductor contact the following methods can be used:

- fusion - in this case, usually using a combine contact and providing certain properties to the contact area of the semiconductor; 
- electrolytic or chemical deposition of metal from solution;

- $\quad$ spraying metal in vacuum;

- covering the surface of the semiconductor with varnish or glue, which is a suspension of metal particles in organic or organosilicon bases;

- electric welding;

- thermocompression welding;

- providing a simple mechanical contact under pressure (clamping contact).

In addition to the necessary electrical properties, contacts must withstand sharp changes in temperature and provide the ability to connect a terminal to a device. Since the power emitted by the device is mainly dissipated through the contacts, the thermal resistance of the contacts should be very insignificant. Although all of the listed methods are possible to use, in most cases, to create a metal-semiconductor contact the process of fusion is used due to its compliance with all the above requirements.

Other methods are also commonly used in combination with [11]. However, the method of creating contacts with electrochemical or chemical deposition is not always reliable. When contacts are made by this method, the surface is usually contaminated. A significant disadvantage of welding method is the low mechanical strength of the contact. The thermocompression method can be used to obtain semiconductor contacts directly with a conductive wire connecting it to the pre-sprayed surface on the semiconductor layer of metal. However, substantive disadvantage of such contacts, except for low mechanical strength, is a limited current value [12].

Some general recommendations for using a number of metals that can serve as contact materials for A3B5, including $\mathrm{GaSb}$, are given in works $[2,5,6,7]$. The creation of ohmic contacts $\mathrm{Pd} / \mathrm{In} / \mathrm{Pd} / \mathrm{Pt} / \mathrm{Au}$ to n-type conductivity $\mathrm{GaSb}$ was investigated in $[3,4]$. A $\mathrm{Pd} / \mathrm{Ge} / \mathrm{Pd} / \mathrm{In} / \mathrm{Pd}$ metallization on $\mathrm{GaSb}$ was doped with Te up to concentration $5.6 \times 10^{17} \mathrm{~cm}^{-3}$ at fusion temperature $350{ }^{\circ} \mathrm{C}$ applied for an hour. The specific contact resistivity as low as $1.4 \times 10^{-6} \mathrm{Ohm} \times \mathrm{cm}^{2}$ and contact resistance of $0.068 \mathrm{Ohm} \times \mathrm{mm}$ were exhibited. $\mathrm{Pd} / \mathrm{Ge} / \mathrm{Pd}$ metallization on GaSb:Te doped to $1.8 \times 10^{18} \mathrm{~cm}^{-3}$ exhibited specific contact resistivities of $3.8 \times 10^{-6} \mathrm{Ohm} \times \mathrm{cm}^{2}$ and contact resistances of $0.058 \mathrm{Ohm} \times \mathrm{mm}$ at fusion temperature $350{ }^{\circ} \mathrm{C}$ applied for an hour. As the authors state, these results [3, 4] represent the lowest reported contact resistance for ohmic contacts to n-type GaSb. The ohmic contacts were created by the fusion of silver $\mathrm{Ag}+1 \% \mathrm{Ga}$. The eutectic Ag-Cu and alloy $\mathrm{Au}+45 \% \mathrm{Ag}+1 \% \mathrm{Ga}$ were studied. The authors of [13] note that the fusion of $\mathrm{Au}+45 \% \mathrm{Ag}+1 \% \mathrm{Ga}$ in the atmosphere of purified hydrogen at a temperature of $530{ }^{\circ} \mathrm{C}$ in $\mathrm{GaSb}$ with both hole and electronic conductivity which creates opportunities to get ohmic contacts. The authors also note that for GaSb crystals of both types of conductivity cracking was not detected after ten-fold cycling in the temperature range from $-196{ }^{\circ} \mathrm{C}$ to $+100^{\circ} \mathrm{C}$ due to the use of such alloys in the fusion area.

The interfacial reactions between $\mathrm{GaSb}$ and $\mathrm{Au}$ were investigated by Rutherford scattering, X-ray diffraction, and cross-sectional electron microscopy in [7]. The degree of decomposition of the GaSb substrate was evaluated first. The results of these metallurgical studies indicate that the reaction between metallization based on $\mathrm{Au}$ or $\mathrm{Au}$ and $\mathrm{GaSb}$ occurs even at temperatures up to $180^{\circ} \mathrm{C}$. However, $\mathrm{Ga}$ and $\mathrm{Sb}$ appear on the contact surface at temperatures above $250{ }^{\circ} \mathrm{C}$. Therefore, the authors [7] note that $\mathrm{Au}$ metallization is not a good choice for ohmic contacts of GaSb-based devices at temperatures above $250{ }^{\circ} \mathrm{C}$.

It is advisable to use tin as an electrode material, because it completely covers the cleaned surface of $\mathrm{GaSb}$. In addition, tin does not corrode because it is soft. This provides a slightly strained contact. Tin also has a relatively low melting point of $232{ }^{\circ} \mathrm{C}$, which allows obtaining contacts by both methods of melting and soldering. Contacts to p-type GaSb samples were created with the use of the undoped tin. Contacts to the n-type samples were made by using tin doped with tellurium. Doped tin was prepared by fusing 99at.\% Sn and 1at.\%Te in the evacuated quartz ampoule. Satisfactory results were achieved by fusing under a layer of flux, which served as rosin.

\section{Experimental procedure}

Omic contacts to the n-type GaSb whiskers were created by means of a current pulse shaper according to the schematic diagram shown in Fig. 1.

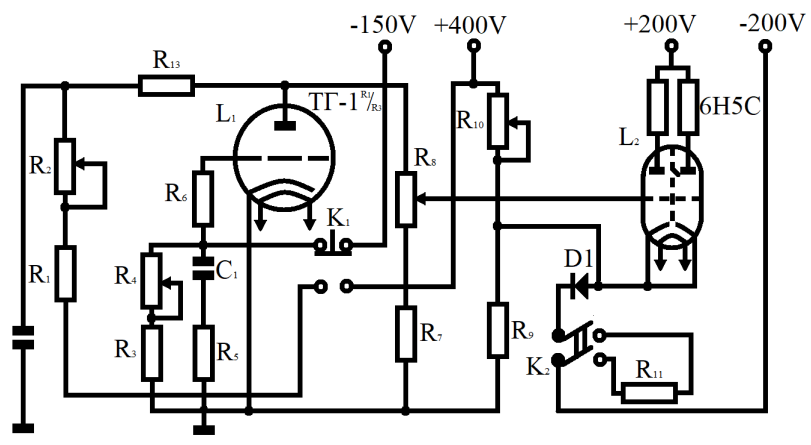

Fig. 1. Schematic diagram of the current pulse shaper.

The operation principle of the current pulse shaper is as follows. The initial position of the switch P1 (K1) is in position 1 . The capacitor $\mathrm{C} 1$ is charged to the voltage of the DC power supply $(150 \mathrm{~V})$. A large negative voltage is applied to the thyratron grid. The circuit of the 
thyratron anode is disconnected from the DC voltage source $(+400 \mathrm{~V})$ and the voltage at the thyratron anode is zero. Thyratron is closed in the initial state. The positive voltage $(170 \div 210 \mathrm{~V})$ is applied to the cathodes of the output lamps, connected in parallel, from the voltage divider, which consists of R9, R10 and R11. The voltage on their grids is zero. The current through the sample marked on the diagram as RN (load resistance) is absent.

The capacitor $\mathrm{C} 1$ is disconnected from a source of $150 \mathrm{~V}$ and begins to discharge through the resistors R3, R4 and R1 when switching the switch P1 (K1) to position 2. The negative voltage on the grid of tiratron begins to decrease by law to change the voltage of the capacitor $\mathrm{C} 1$. The discharge rate of the capacitor $\mathrm{C} 1$ depends on the value of the resistances of the resistors that are included in the discharge circuit. Negative voltage drop rate can be controlled by changing the discharge resistance on the thyratron grid. The capacitor $\mathrm{C} 2$ starts charging. The voltage will increase at the anode of the thyratron as the capacitor $\mathrm{C} 2$ is charged. This voltage is supplied to the grid of output lamps from the voltage divider R7, R8. The output lamps open and a welding current will flow through them. At some ratio of the increasing voltage to the decreasing voltage on the anode that is determined by the parameters of the thyratron, it is ignited and shorted by the voltage divider $\mathrm{R} 7, \mathrm{R} 8$. The voltage on the thyratron grid decreases so much that the thyratron continues to burn. To return the circuit to its initial state, it is necessary to switch P1 (K1) to position 1 . The amplitude of the welding current pulses can be set by changing the resistances of resistors $\mathrm{R} 8, \mathrm{R} 11$. However, it is more convenient to do this by changing the anode voltage of the output lamps. The pulse duration is mainly controlled by changing the resistance of the discharge section of the capacitor $\mathrm{C} 1$ (using potentiometer R4).

A slide table was made for welding ohmic contacts to GaSb whiskers. The bath with microfurnace was fixed on the table. The scheme is presented in Fig. 2. The welded microwire 7 with a diameter of $30 \mu \mathrm{m}$ is fixed in a clamp connected with the micrometer screws 10 . Micrometric screws allow us to move the clamp with the microwire 7 smoothly in three directions. That provides the supply of the tip of the wire 8 to a given point on the surface of the monocrystals 6 . The proposed method is a kind of the fusion that is carried out under flux being one of the most suitable techniques for creating contacts to the whiskers grown by the method of gas transport reactions. A gold microwire with a diameter of $30 \mu \mathrm{m}$ was used as the contact material.

It is known that strong local overheating of the semiconductor material causes the formation of impurity defects in the place of overheating. These defects have acceptor properties reducing the quality of the ohmic contact. To prevent this phenomenon, the crystal is preheated to a temperature of $300{ }^{\circ} \mathrm{C}$ in such a way that a small current pulse passed through the sample is sufficient to obtain an eutectic Au-GaSb. A microfurnace 4 built into the ceramic bath 1 was used for this purpose. The furnace is filled with a mixture of silicate glue and talc 3. After drying this paste, the small bath with an equal bottom is formed. To prevent some roughnesses, the ceramized plate 5 can be glued to the bottom of the bath with the same putty. A gallium antimonide whisker 6 is placed on this plate and pressed with a platinum clamp 8, as shown in Fig. 2. Bronze foil 9 served as an elastic element of the clip 11. Then rosin 12 is poured into the bath. Rosin is melted by heating the crystal to a temperature of $300{ }^{\circ} \mathrm{C}$.

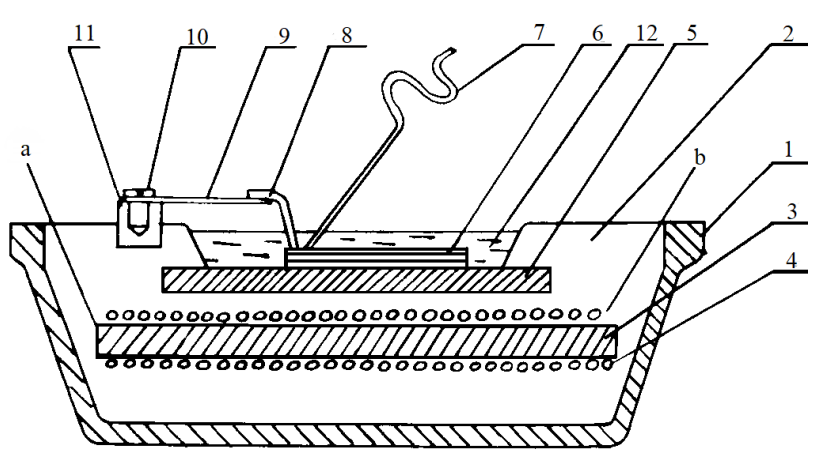

Fig. 2. Scheme of welding contacts to GaSb whiskers: bath (1), solution (2), mixture (3) micro-furnace (4), ceramized plate (5), monocrystals (6), microwire (7), platinum clamp (8), bronze

foil (9), micrometer screws (10), clip (11), rosin (12).

The tip of the contact microwire 7 is moved to the end of the crystal in an area close to the platinum clamp 8 . The circuit of the current pulse is closed according to the scheme: shaper - gold microwire - small section of the whisker - platinum clamp - shaper.

As noted, the current pulse passes through this small section of the whisker. As a result, the main part of the whisker is not overheated that could influence its electrophysical properties. It should be pointed out that this part of the whisker is the base of the element sensitive to comprehensive compression. Current welding modes are selected by testing. These welding modes depend mainly on the thickness of the investigated whisker. The operation is repeated after welding one of the electrodes.

\section{Experimental results and discussion}

To conduct experiments for determining the electrophysical parameters, it is first necessary to make sure that the contacts are ohmic. The I-V characteristics of the contacts were measured. At least three contacts (two contacts on the edges of whisker and the investigated one - in the middle of it) were created to study the I-V characteristics of the contact. The results of the studied I-V characteristics are shown in Fig. 3. 


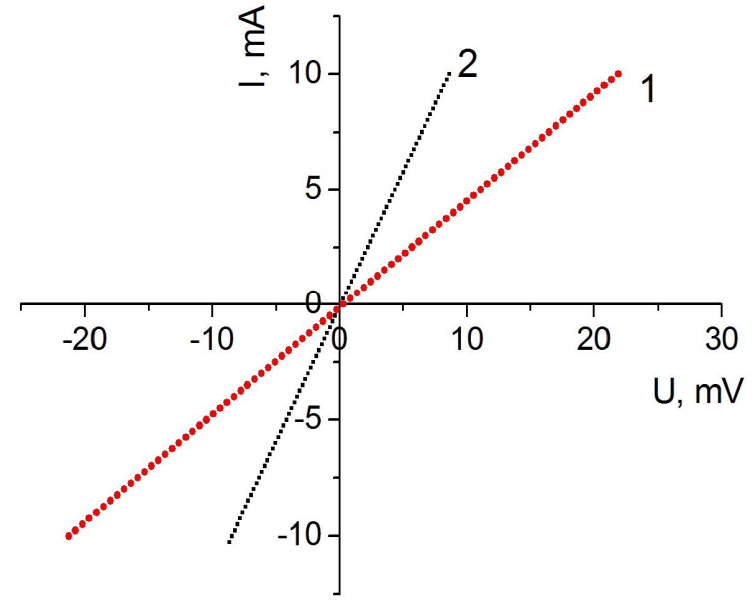

a)

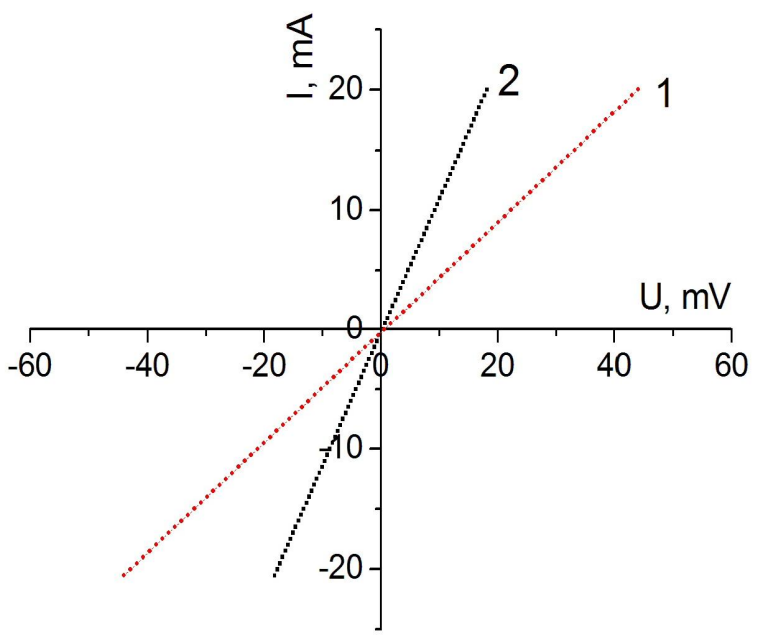

b)

Fig. 3. I-V characteristics of GaSb whiskers with a diameter of $12 \mu \mathrm{m}(\mathrm{a})$ and $20 \mu \mathrm{m}(\mathrm{b})$ at temperatures $4.2 \mathrm{~K}(1)$ and $77 \mathrm{~K}(2)$.

As it can be seen from Fig. 3, obtained I-V characteristics at low temperatures are linear, regardless of the direction of current transmission that allows using this method to create electrical contacts and study the electrophysical characteristics of $\mathrm{GaSb}$ whiskers. The samples of $\mathrm{GaSb}$ with diferent resistances with diameters $12 \mu \mathrm{m} R_{4.2 K}=2.32 \mathrm{Ohm}, R_{77 K}=0.87 \mathrm{Ohm}$; and $20 \mu \mathrm{m} R_{4.2 K}=2.31 \mathrm{Ohm}, R_{77 K}=0.92 \mathrm{Ohm}$ were studied.

The Hall potential difference and electrical conductivity of the samples were measured to determine the physical properties of the charge carriers that allowed to estimate their concentration and mobility $\mu_{H}$. In addition to the Hall EMF, other galvanic and thermomagnetic effects can contribute to the total voltage during measurements. Therefore, it is necessary to use a five-contact circuit, shown in Fig. 4. The contacts to GaSb whiskers created in this way meet all the requirements for ohmic contacts. To study the mechanical properties of the whiskers, the mechanical strength of their contacts was measured using a special installation. A force was applied at an angle of $45^{\circ}$ to normal in the plane of welding. A rupture of the gold microwire was revealed in all cases. Consequently, the strength of contacts exceeds the strength of the microwire. The proposed method allows creating ohmic contacts to GaSb whiskers grown by the method of gas transport reactions $[14,15]$. The minimum sizes of the studied whiskers were determined due to their microwire thickness. In our case, the minimum whisker thickness was $20 \mu \mathrm{m}$. There are no restrictions on welding ohmic contacts to thick monocrystals.

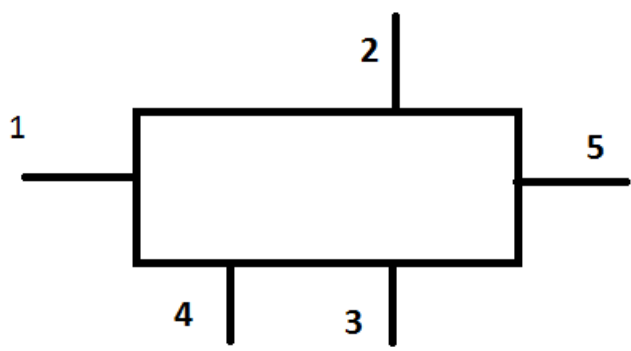

a)

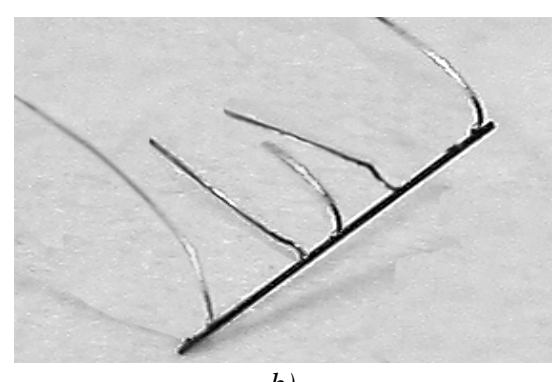

b)

Fig. 4. Schematic arrangement of contacts on the sample for Hall measurements (a); photo of a GaSb whisker with contacts ( $b$ )

\section{Conclusions}

The use of rosin as a flux is caused by the following conditions. Preheating the crystal to the melting point of rosin reduces the amplitude of the welding pulse and, consequently, the concentration of defects associated with the peculiarities of the contact creating method. Defects in the welding place have an acceptor nature. The $\mathrm{p}-\mathrm{n}$ junction in the welding place is obtained due to welding of ohmic contacts to n-type conductivity whiskers. Therefore, it is necessary to take measures to reduce the concentration of welding defects. Rosin isolates the crystal from the atmosphere and prevents the adsorption of oxygen during welding. Welding under rosin improves the mechanical properties of the contacts.

Contact resistance was determined being $0.5 \mathrm{Ohm}$ due to studies of samples with resistance $0.8-1 \mathrm{kOhm}$. Improving the quality of contacts can be achieved by 
making the alloy of $50 \% \mathrm{Au}+50 \% \mathrm{Ag}+1 \% \mathrm{Te}$ for the microwire material, or due to doping the gold microwires by their immersing in tin with the addition of $1 \%$ tellurium.

\section{References}

[1] N. Rahimi, A. A. Aragon, O. S. Romero, D. M. Shima, T. J. Rotter, S. D. Mukherjee, G. Balakrishnan, and L. F. Lester, "Electrical and microstructure analysis of nickel-based lowresistance ohmic contacts to $\mathrm{n}-\mathrm{GaSb}$ ", $A P L$ Materials, no. 1(6), pp. 062105, 2013.

[2] A. A. Vasiliev, A. M. Mozharov, F. E. Komissarenko, G. E. Cirlin, D. A. Bouravlev, and I. S. Mukhin, "Researching the electrical properties of single A3B5 nanowires". In Journal of Physics: Conference Series, vol. 917, no. 3, pp. 032-042, November 2017.

[3] K. Ikossi, M. Goldenberg, and J. Mittereder, "Metallization options and annealing temperatures for low contact resistance ohmic contacts to n-type GaSb", Solid-State Electronics, no. 46(10), pp. 1627-1631, 2002.

[4] J. A. Robinson and S. E. Mohney, "An improved In-based ohmic contact to n-GaSb", Solid-State Electronics, no. 48(9), pp. 1667-1672, 2004.

[5] K. A. Dick, "A review of nanowire growth promoted by alloys and non-alloying elements with emphasis on Au-assisted III-V nanowires Progress in Crystal", Growth and Characterization of Materials, no. 54(3-4), pp. 138-173, 2008.

[6] A. Subekti, V. W. L. Chin, and T. L. Tansley, "Ohmic contacts to n-type and p-type GaSb", Solid-State Electronics, no. 39(3), pp. 329-332. 1996.

[7] A. Piotrowska, E. Kaminska, T. Piotrowski, S. Kasjaniuk, M. Guziewicz, S. Gierlotka, X. W. Lin, Z. Liliental-Weber, J. Washburn, and S. Kwiatkowski, "Interaction of $\mathrm{Au}$ with $\mathrm{GaSb}$ and its Impact on the Formation of Ohmic Contacts", Acta Physica Polonica-Series A General Physics, no. 87(2), pp. 419-422, 1995.

[8] C. H. Lee, G. H. Lee, A. M. Van Der Zande, W. Chen, Y. Li, M. Han, X. Cui, G. Arefe, C. Nuckolls, T. F. Heinz, J. Guo, J. Hone, and P. Kim, "Atomically thin $\mathrm{p}-\mathrm{n}$ junctions with van der Waals heterointerfaces", Nature nanotechnology, no. 9(9), pp. 676, 2014.

[9] D. Jena, T. Fang, Q. Zhang, and H. Xing, "Zener tunneling in semiconducting nanotube and graphene nanoribbon $\mathrm{p}-\mathrm{n}$ junctions", Applied Physics Letters, no. 93(11), pp. 112106, 2008.
[10] Y. Zhang, R. Suzuki, and Y. Iwasa, "Potential profile of stabilized field-induced lateral $\mathrm{p}-\mathrm{n}$ junction in transition-metal dichalcogenides", ACS nano, no. 11(12), pp. 12583-12590, 2017.

[11] S. S. Gavryushin and P. A. Skvortsov, "Evaluation of output signal nonlinearity for semiconductor strain gage with ANSYS software", In Solid State Phenomena", Trans Tech Publications Ltd, Vol. 269, pp. 60-70, 2017.

[12] K. F. Brennan and A. S. Brown, Theory of modern electronic semiconductor devices. New York, USA: John Wiley, 2002.

[13] D. Maksimovic, A. M. Stankovic, V. J. Thottuvelil, and G. C. Verghese, "Modeling and simulation of power electronic converters", Proceedings of the IEEE, no. 89(6), pp. 898-912. 2001.

[14] I. Khytruk, A. Druzhinin, I. Ostrovskii, Y. Khoverko, N. Liakh-Kaguy, and K. Rogacki, "Properties of doped GaSb whiskers at low temperatures", Nanoscale research letters, no. 12(1), pp. 1-8, 2017.

[15] S. S. Warsaw, N. S. Liakh, and N. M. Stasiuk, "Nonlinear effects in point contacts metal-silicon, metal-silicon-germanium", Physics and Chemistry of Solid State, no. 2 (4), pp. 727-734, 2001.

\section{ОМІЧНІ КОНТАКТИ ДО НИТКОПОДІБНИХ КРИСТАЛІВ АНТИМОНІДУ ГАЛІЮ N-ТИПУ ТА Р-ТИПУ ПРОВІДНОСТІ}

Анатолій Дружинін, Ігор Островський, Юрій Ховерко, Олексій Кутраков, Наталія Лях-Кагуй, Дмитро Чемерис

За допомогою формувача струмових імпульсів створено омічні контакти до ниткоподібних кристалів антимоніду галію $n$-типу провідності. Їх $\mathrm{BAX}$ за низьких температур $є$ лінійними незалежно від напряму пропускання струму, що дає змогу використовувати описаний метод для створення електричних контактів і дослідження електрофізичних характеристик ниткоподібних кристалів $\mathrm{GaSb}$. Дослідження проведено для зразків діаметром 12 мкм та 20 мкм за температур 4,2 К та 77 К. Для приварювання омічних контактів до кристалів GaSb виготовлено предметний столик, на якому закріплено ванночку 3 мікропіччю. Як контактний матеріал використано золотий мікродріт діаметром 30 мкм, а вплавлення здійснено під шаром флюсу. Цей спосіб є різновидом вплавлення і одним із найпридатніших методів для створення контактів до ниткоподібних кристалів, вирощених методом газотранспортних реакцій. 


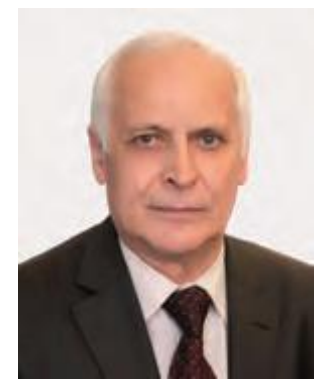

Anatoliy Druzhinin - DSc., professor, Head of the Department of Semiconductor Electronics at the Institute of Telecommunications, Radio-electronics and Electronic Engineering, Lviv Polytechnic National University, Ukraine. He is also the winner of Ukrainian State Prize in Science and Technology (2011), Honored Research Worker of Science and Technology of Ukraine. The main scientific activities of prof. A. Druzhinin include: theoretical and experimental study of strain-induced effects in silicon, germanium and their solid solutions whiskers. Prof. Druzhynin has authored more than 140 scientific publications indexed in scientometric databases in Scopus and Web of Science and more than 50 invention certificates and patents. Under his supervision 6 DSc and $11 \mathrm{PhD}$ degrees in technical science were obtained.

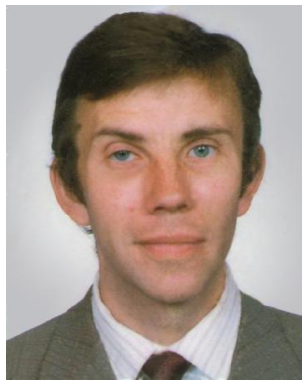

Ihor Ostrovskii - DSc., professor, professor of the Department of Semiconductor Electronics at the Institute of Telecommunications, Radioelectronics and Electronic Engineering, Lviv Polytechnic National University, Ukraine.

His main scientific activities include: theoretical and experimental study of strain-induced effects in silicon, germanium and their solid solution whiskers. Prof. Ostrovskii has authored more than 400 scientific papers including more than 20 inventor's certificates and patents.

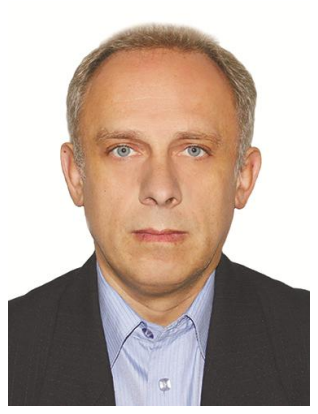

Yuriy Khoverko - DSc., professor, professor of the Department of Semiconductor Electronics at Lviv Polytechnic National University. Research interests cover the physics and technology of semiconductor devices, micro- and nanoelectronic structures and sensor electronics.

Research findings are published in more than 200 scientific papers and more than 10 Ukrainian patents.

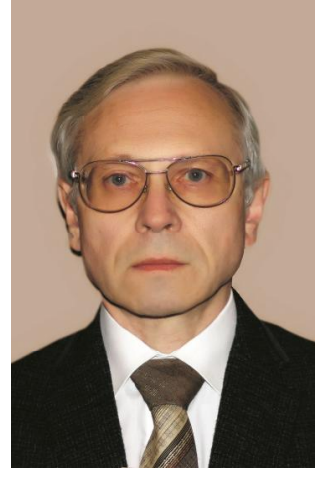

Oleksiy Kutrakov - PhD, Senior Researcher of the Department of Semiconductor Electronics at the Institute of Telecommunications, Radio-electronics and Electronic Engineering, Lviv Polytechnic National University, Ukraine. Research interests: development of sensors of mechanical quantities based on filamentous crystals of silicon, germanium and A3B5 compounds and studies of their characteristics.

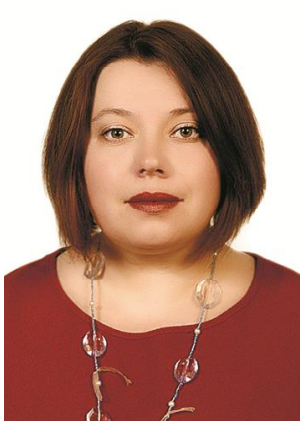

Natalia Liakh-Kaguy - DSc, Associate Professor of the Department of Semiconductor Electronics at the Institute of Telecommunications, Radioelectronics and Electronic Engineering, Lviv Polytechnic National University, Ukraine. Researcher has authored more than 100 scientific papers including 10 patents by Ukraine.

Her scientific activities are connected with theoretical and experimental studies of electrophysical and magnetotransport properties of silicon, germanium and A3B5 whiskers being used in micro- and nanosystem technology.

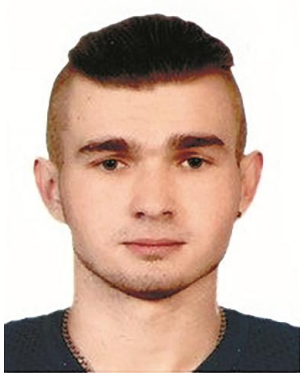

Dmytro Chemerys - postgraduate student of the Department of Semiconductor Electronics at the Institute of Telecommunications, Radio-electronics and Electronic Engineering, Lviv Polytechnic National University, Ukraine. Research interests cover the physics and technology of semiconductor devices, robotics and sensor electronics.

Received: 18.03.2021. Accepted: 25.04.2021 